\title{
ANALYSIS OF THE MOTIVATIONAL SPEECH HELD BY THE NATIONAL TEAM COACH BEFORE THE FINAL FIFA U-20 WORLD CUP MATCH
}

\author{
Branka Savović $^{1}$, Milica Ubović ${ }^{2}$, Sandra Radenović \\ ${ }^{1}$ University of Belgrade, Faculty of Sport and Physical Education, Serbia \\ ${ }^{2}$ Prijatelji dece Beograda, Citizens' Association
}

\begin{abstract}
In modern literature, it is most often stated that a sports coach should be moral, autoritative, educated, communicative, etc. Undoubtedly, a coach should be such a person, but we know relatively little about what a successful coach really is. A coach is driven by his knowledge, experience, but also by his implicit philosophy, i.e. deeper and hidden motivational factors, beliefs and attitudes about himself, his own role as well as about individual athletes or a team as a whole. Practice has shown that these coaching attributes affect functioning of a sports team. The aim of this paper was a pedagogical overview of a sports coach's educational work. The subject of this paper referred to the knowledge that could be classified into the implicit philosophy of a successful coach. The methodological context was the application of the discourse analysis in semantic and meaningful identification of a successful coach's motivational speech. Searching for an answer to the aim and subject of this paper, we performed the analysis of the motivational speech held by the national coach Paunovic to the players of Serbian U-20 football national team before the final FIFA U-20 World Cup match against Brazil in New Zealand (2015). Applying some methodological steps, the speech of the coach Paunović was divided into three discourse units, analyzed through the messages he sent to the players. The results of the analysis indicate that the coach's messages were characterized by dignity as well as by calling for unity and responsibility. There were no messages relating to depreciation or exaggeration of the opponent's team, there were no professional advice, threats or expressing negative emotions. The conclusion of this analysis implies explicit messages relevant for pedagogy, psychology, sports axiology, but also for technology of sports and football respectively.
\end{abstract}

Key words: DISCOURSE ANALYSIS / NATIONAL TEAM COACH / MOTIVATIONAL SPEECH / FIFA WORLD CUP / FOOTBALL / SERBIA

\section{INTRODUCTION}

In modern literature, there is a relatively large number of studies dealing with the research of personality traits and characteristics of a quality sports coach. It is most often stated that a coach should be moral, authoritative, well-educated, team player, communicative and competent, etc. (Galić, 2010; Oljača, 2001). Robinson (2010) stated that it is important for a coach to be good at planning and analytics or to be someone who is capable of creating and maintaining the "safe environment" suitable for training, growth and development of each individual. A coach is able to communicate effectively with others, providing constructive feedback as well as motivated for continuous learning and development (Crisfield et al., 2003). This job description frequently includes unconditional love and acceptance as something that should be cherished and nurtured by coaches in their work with individuals, groups or entire teams. Showing concern about each individual athlete, i.e. player, showing interest in what is happening in their private lives makes and develops a sense of unity and acceptance by each team member within a team or group. Coaches should constantly learn and develop, i.e. their openness to learning is of utmost importance (Cassidy et al., 2004). In technological and educational sense, the job of a coach is a complex process which is filled with interactive learning. Furthermore, learning is a process of constructing mean- 
ings, i.e. a permanent social process where meanings are exchanged through one's one work and activities (Krnjaja, 2009). A coach is a person who is constantly learning through his interaction with others (players, associates, audience, supporters, etc.) thus changing both himself and his attitude towards the profession as well as contributing to the community where he lives. In this paper, the coach was considered a leader and a team player as well as an associate within a learning process who respects the characteristics and experiences of each individual and strives to achieve common goals. Through his partnership with many actors, based on respect and importance distribution, dialogue and construction of common meanings, a coach creates a team's common framework as well as the environment where each actor can learn, develop and improve. In addition to his education, upbringing and qualities gained through experience, each coach has his own implicit professional philosophy. Implicit professional philosophy indicates deeper and hidden motivational factors that define him as a coach. This field is difficult for analysis in developing professional competences and it is also filled with beliefs and attitudes about oneself, one's own role, a team, a current situation and the team's future tasks as well. Practice has shown that exactly these beliefs of a coach directly affect a team's functioning. The implicit professional philosophy of a coach could be observed as a set of moral beliefs and stances which shape his behaviour in different professional and life situations, whereby, different coaches have different implicit professional philosophies about their own role within a team, i.e. the reason for which they are engaged in coaching (Robinson, 2010). Coaches' implicit philosophies may also affect the way they perceive individual players and associates as well as the nature of establishing their relationships. Therefore it is important that, during the process of developing his professional competences, a coach should be aware of his own implicit philosophy and the fact that the process of professional development should be followed by analysis and changes in his own beliefs and attitudes. It is important that this process is continuous, i.e. before, during and after specific training and competitive activities. It is also important that a coach himself is aware of that his own beliefs and attitudes as well as his experience can influence the pedagogical decisions he makes during his work.
Since the subject of this paper was the analysis of the motivational speech held by the coach before the deciding match, it is therefore important to point out the significance of the speech for the course of the match itself. Motivational speeches are those that inspire and increase the efficient work of the team itself, where we can distinguish three speech types (Vargas-Tonsing \& Bartholomew, 2006): (i) speech of „control“, (ii) strategy-oriented speech and (iii) emotional speech which is defined by the authors as the one which motivates players most, since it includes strong emotions regarding possible success of a team. The speech content is of special importance since through it a coach can express his intimate and deep emotions in relation to the upcoming match as well as his huge desire that his team should play with confidence and pride (Leidl, D. \& Frontiera, 2009).

There is an insufficient number of scientific records related to the study of what a successful coach is. The personality of every man is based on an orginal genetic structure. The characteristics of a person also depend on their life and sports experience, but also on the quality of their education, which constitutes thier personal and implicit philosophy. Therefore, the aim of this paper was to collect more facts in order to determine the performance of the successful coach at the moment of a deciding sports event. By applying the discourse analysis as a method used in this paper, we tried to determine his attitudes, beliefs, emotions, etc. which are included in his professional dynamics and which, at the same time, make him special.

Discourse is recognized both as a source of knowledge and as a process during which verbal and non-verbal communication is analyzed in relation to a specific context. Speech and context constitute a communicative situation. In other words, a text (speech) and a context represent a communicative unit, suitable for discourse analysis. By analyzing a speech or a dialogue (semantic and linguistic context), a researcher examines and searches for the meanings and values arising out of the content of the analysis (methodological context). Thus, he tries to identify and verify the implicit philosophy of the persons who take part in the communicative situation.

The aim of this paper was to analyze the communicative situation where the coach was addressing the players before the deciding match - the World Cup finals. Specifically, we analyzed the speech held by 
Mr. Veljko Paunović, a coach of the national under-20 football team of the Republic of Serbia, before the final U-20 FIFA World Cup match against the national team of Brazil. The match was played on 2015 FIFA U-20 World Cup in New Zealand, Auckland. In this match, Serbian U-20 national team won against Brazil 2:1. The reason for this analysis was the affirmation of the authors' scientific and professional curiosity, incited by the practical issues and statements presented in the Serbian public, as follows:

- the coach was most responsible for the success of the Serbia's U-20 national team. His motivational speech before the final match left a lasting impression on the professional and general public;

- the players pointed out the coach's leadership and his motivational speech before the final match as a factor of importance for the match outcome.

In training practice, it is known that a match can be won (or lost) by winning the inner, mental game. It often happens that a strong opponent loses a match against a potentially weak one (and vice versa) due to players' implicit beliefs. In addition, a coach's motivational speech before a match, according to the professionals as well as the players, significantly influence the players during the competition itself. Coaches' motivational speeches before finals are quite diverse. Thanks to modern technology and a growing need for highlighting the practice and behaviour models of the successful, these speeches have been recorded and analyzed nowadays. Thus, by searching the Internet, one can find the blogs including „,oaches' best motivational speeches". Only by listening to these speeches, it can be noticed that they differ in many factors. These differences stem from the traits of a coach, i.e. his players, but also in relation to a competitive situation and the cultural values which are cherished in a given society.

Thus, some recordings of motivational speeches abound with battle cries and battle music in their background. There are also speeches which are, contrary to any sports values, full of efforts to humiliate the opponent. It seems that different motivational speeches fit into cultural values, since the players have responded positively to the speech. Therefore, one of the research questions may be whether a conclusion about the society the players come from may be drawn by analyzing a communicative context in sports. Certainly, it is possible to search for the answer to this question only when the athletes belong to the same cultural community. Unlike the heteroge- neity of professional teams, there is a pronounced homogeneity present in national teams. Therefore, one of the research questions, which could be discussed, would be: which speech elements represent a good motivational incentive for Serbian football players? Finally, this research problem was pedagogically oriented. We tried to determine whether the motivational speech addressed to the young players included any educational contents and to what extent.

\section{METHOD}

The method used in this paper was discourse analysis. Discourse analysis is a research approach suitable for searching for the meaning of a text within a given context (Ber, 2001). As a type of pedagogical analysis it has been widely used since 1988, i.e. after publishing the article on classroom discourse analysis by Courtney, a professor responsible for initiating a course of the same name at Harward Univeristy. Since then, it has had many methodological, semantic, linguistic, gnoseological, epistemological variations (Gee, 1996, Faircough 2003, Ber, 2001). Today it is considered one of the most recognized sociological and pedagogical qualitative analysis which leads to objective qualitative conclusions.

Methodological steps in the realization of discourse analysis were supplemented by the text analyses by applying two software programs. Voyant is the first application for performing text analysis applied in this paper. The program is designed to indicate word frequency and links within a text as well as to identify distribution plots in the text. Another application used was LIWC (Linguistic Inquiry and Word Count software program, currently the best rated application for text analysis (Bjekic et al., 2012). The authors of this paper are aware of the current linguistic as well as methodological restrictions of the Serbian version of this software. Therefore, the English version was applied. For the purpose of the analysis, Mr. Paunovic's speech was translated into English, analysed using the LIWC sofware and then the results were translated into Serbian and presented in tables.

The application of the LIWC software tool enables a quantitative analysis of the words used. Each single word is recognized by the program as a unit belonging to a particular category. Categories are necessary to determine the meaning of a word in relation to the 
context. The program itself contains about 4500 predefined categories through which the entered text is compared and analysed. Since the program identifies grapheme composition of each word and registers it contextually, as a linguistic category, it can also determine a linguistic style of the speaker. Through the linguistic style, the program recognizes speech attributes and points out the basic dimensions of the analysed person's behaviour. For instance, the "Cooperation" dimension, distinguished in the software scheme, is in a negative correlation with the words that contextually reflect negative emotions. Extraversion correlates with the words that express positive emotions and which contextually indicate social processes. It is also associated with the overall word production by a person who, in a less formal language, using the pronouns in the second and third person plural, marks social awareness and engagement (Pennerbaker et al., 2003 according to Bjekic et al., 2012). The „Conscientiousness" dimension positively correlates with using the pronouns in the second person plural as well as with positive emotions, etc. The application analyses the entered data in relation to the average common personal texts, messages (informal talks) and in relation to formal texts (public speeches, business correspondence, lectures, etc.).

\section{RESULTS AND DISCUSSION}

The motivational speech by the national coach Paunovic and the context where it was published has become public (and thereby available to the analysis) via modern media (http://mondo.rs/a806821/Sport/ Fudbal/Veljko-Paunovic-sampionski-govor-pred-finale-Srbija-Brazil.html). We have presented it in its entirety:

"All of us have to take a maturity test. After all, our maturity is challenged today in the best and most beautiful way. It is our graduation day today, a football one. We are playing the World Cup final match against the best opponent in the world. Against Brazil. And I want to tell you we need to enjoy today. There should be no pressure, except our desire to win. It is the basic urge we were born for, that is why we play football. To enjoy and win, is that right? I want to tell you that no one should excell today. You have already done that. In what sense? Individually, fighting for your own reputation. All of you who are here today, everybody already knows about you. Top professional careeres are waiting for you. Today we need to play for the team. Today we need to be united, as we have been so far. And even more! Whoever our opponent is, we, guys, deserve it. This trophy (pointing to the photo). We, guys, are born for this, to win this trophy. Look at it closely, it should be ours. Anyway, we should only give our best. As we have been doing so far. Today, we need to seal a victory (hitting his fist against his palm). Today is our graduation day! (another "seal" with a fist). Today we are taking the final exam, we are graduating today! We are going home with the gold! I want you all guys to stand up. I want you all to hug each other, as we did last time, please hug each other. And guys, I don't want you to pray now, I want you now to look each other in the eyes. Anyone who needs to keep their eyes closed, let them do it. And think about why we are worth it. What everyone of you has done in their life and why (pointing to the trophy in the photo). Who everyone of us is and who we want to win this for. Please hug each other, let us feel each other. Let's remain silent for a minute. To feel the unity. To look each other in the eyes and tell to each other that we are going to do it for each other. To do it for us, for all of us."

The speech by Mr. Paunović lasted 2 minutes and 66 seconds. A total of 325 words was used. The context in which it was spoken was as follows: New Zealand, the team's last meeting before the final match, a teams' meeting room. The coach was standing facing the players, with a screen behind him.

The context was analyzed at several levels. At the first level it was divided into three meaningful units as follows: (1) Awareness (2) Task and (3) Calling for unity and uniqueness.

In methodological terms, the "Situation Awareness" (hereinafter referred to: Situation) included the following parts of the text: „All of us have to take a maturity test. After all, our maturity is challenged today in the best and most beautiful way. It's our graduation day today, a football one. We are playing the World Cup final match against the best opponent in the world. With Brazil. And I want to tell you we need to enjoy today. There should be no pressure, except our desire to win. It is the basic urge we were born for, that's why we play football. To enjoy and win, is that right?" 
The meaningful unit „Task“ included the following parts of the text:

„I want to tell you that no one should excell today. You have already done it. In what sense? Individually, fighting for your own reputation. All of you who are here today, everybody already knows about you. Top porfessional careers are waiting for you. Today we need to play for the team. Today we need to be united, as we have been so far. And even more! Whoever our opponent is, we, guys, deserve it. This trophy (pointing to the photo). We, guys, are born to win this trophy. Look at it closely, it should be ours. Anyway, we should only give our best. As we have been doing so far. Today we need to seal a victory (hitting his fist against his palm). Today is our graduation day! ( $a$ new „seal“ with the fist). Today we are taking our final exam, we are graduating today! We are going home with the gold!“

The meaningful unit „Calling for unity and uniqueness" (hereinafter referred to: Call) included the following parts of the text:

"I want you all guys to stand up now. I want you to hug each other,as we did last time, I want all of us to hug each other. And, guys, I don't want you to pray now, I want you to look each other in the eyes. Anyone who needs to keep their eyes closed, let them do it. And think about why we are worth it. What everyone of you has done in their life to deserve this (pointing to the trophy in the photo). Who everyone of us is and who we want to win this trophy for. Please hug each other, let us feel each other. Let's remain silent for a minute. To feel the unity. To look each other in the eyes and tell to each other that we are going to do it for each other. To do it for us, for all of us."

In the following step, the entire text as well as each individual unit were analyzed separately.

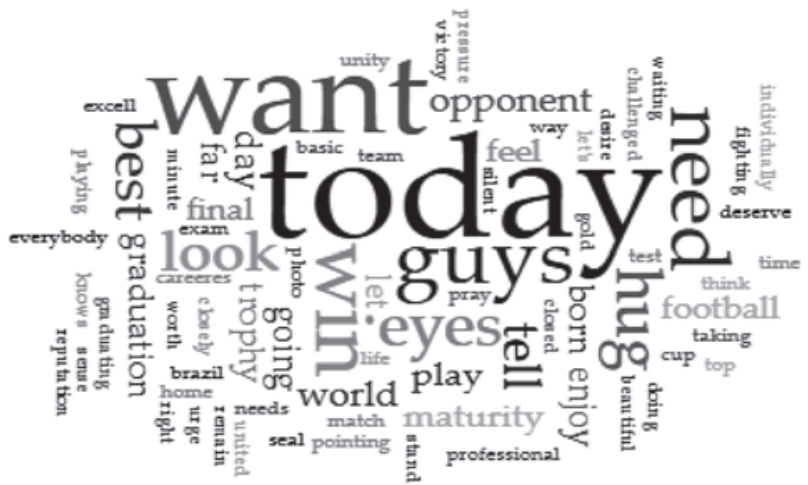

Figure 1: The most frequent words in the speech by the national coach Paunovic (the result of the analysis performed by the Voyant software tool for text analysis)
Based on the font size, the frequency of specific words was visually assessed. By looking at the Figure 1 , it can be observed that the text is dominated by the following words: to, today, enjoy, win, play, and pressure. These words represent a backbone of the entire message. Generally, except for the word „pressure“, all other words express positive messages and emotions addressed to the players. The links between the most frequent words in the entire text have been shown in Figure 2:

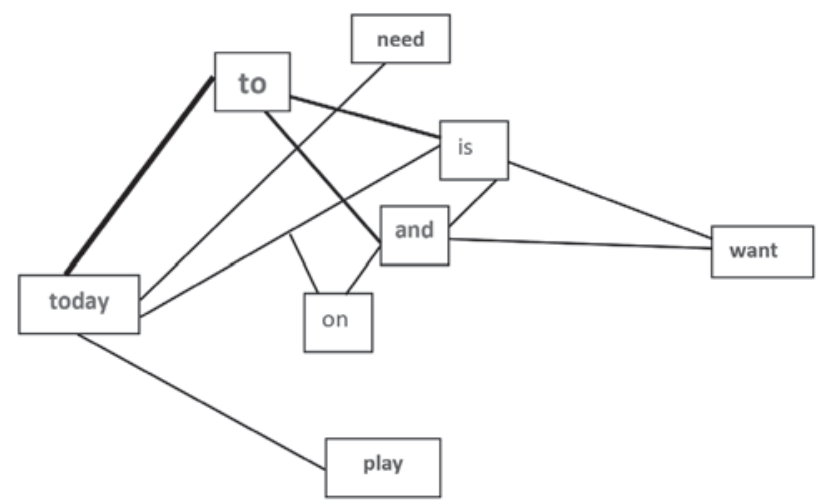

Figure 2. The links within the analyzed speech by the coach Paunovic

It is dominated by the words need, to, want, play, today. The particle to is central in grammatical term and it has no semantic meaning, since it links the expressions need, want, today and play. By analyzing the links within the text it can be noticed that the coach emphasized the value of the game itself, and not that of the victory or competition. He did not insisted on pressure. Thinking about the opponent is not preferred. There are no threats, the seriousness of the situation is not emphasized. This speech analysis has become even clearer when verbal plots within the text are observed (Figure 3).



Figure 3. The links within a verbal plot of the "Task“ unit 
As presented in Figure 3, the main message of the national coach to the U-20 national team was „I want, we need to, we want to enjoy, win today. These, positively oriented discourse messages dominate the entire text as well. The LIWC analysis also determined that the text differs from common formal and personal messages (Table 1).

Table 1. The text analysis of the speech by the coach Paunovic (LIWC software tool)

\begin{tabular}{|c|c|c|c|}
\hline LIWC analysis & Coach's speech & $\begin{array}{c}\text { Personal messages } \\
\text { (mean values) }\end{array}$ & $\begin{array}{c}\text { Formal speech } \\
\text { (mean values) }\end{array}$ \\
\hline Personal reference (I, my, me..) & 9,27 & 11,4 & 4,2 \\
\hline Social words (we, all, ours..) & 16,29 & 9,5 & 8,0 \\
\hline Positive emotions & 3,65 & 2,7 & 2,6 \\
\hline Negative emotions & 0,84 & 2,6 & 1,6 \\
\hline
\end{tabular}

The results of the LIWC analysis were translated into Serbian, and all the tables were adjusted to the specific tasks of this analysis. The results indicate that Mr. Paunovic used a considerably higher number of social words (we, want, all, etc.), i.e. a considerably higher number of the words that contextually indicate positive emotions and a considerably small number of the words expressing negative emotions in relation to their mean values in personal and formal speech.

Starting from the model analysis of the Task unit, the analyses of the other two situations were performed. Collectively, all the three situations that were singled out and analyzed have been presented in Figure 4.


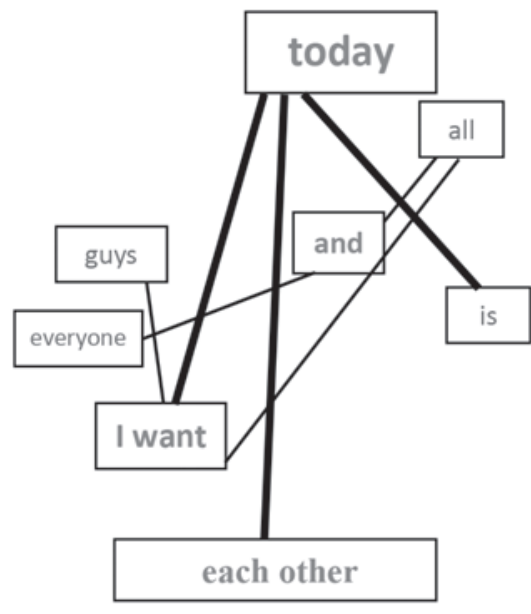

Figure 4. A display of the links within the discourse units

In the first discourse unit, the textual links were established between the words and compounds „Today, we have, enjoy, no (pressure)". The second unit was dominated by „Today, we need to, pass, anyway“, and the third one included "Guys, today, I want, each other, all, everyone“.

The comparative discourse analysis of all the three situations has been presented in the Table 2 . 
Savović B. et al., Analysis of the motivational speech..., PHYSICAL CULTURE 2018; 72 (1): 102-110

Table 2. The analysis of the text discourse units (LIWC software tool)

\begin{tabular}{|c|c|c|c|c|c|}
\hline \multirow[b]{2}{*}{ LIWC analysis } & \multicolumn{3}{|c|}{ Discourse units } & \multirow{2}{*}{$\begin{array}{c}\text { Personal messages } \\
\text { (mean values) }\end{array}$} & \multirow{2}{*}{$\begin{array}{l}\text { Formal speech } \\
\text { (mean values) }\end{array}$} \\
\hline & Situation & Task & Call & & \\
\hline Personal reference (I, my, me..) & 10,71 & 10,16 & 9,77 & 11,4 & 4,2 \\
\hline Social words (we, all, ours..) & 10,71 & 20,31 & 13,53 & 9,5 & 8,0 \\
\hline Positive emotions & 10,71 & 3,12 & 0,75 & 2,7 & 2,6 \\
\hline Negative emotions & 2,38 & 1,56 & 0.00 & 2,6 & 1,6 \\
\hline
\end{tabular}

Mr. Paunović used a greater number of social words („we, us") than it is usual in personal and formal speeches. The largest number of such words has been registered in the second discourse unit, conditionally called the "Task”. The text shows that the coach used these words when he talked about the future, arduous venture: „Today we need to play for the team. Today we need to be united, as we have been so far. And even more! Whoever our opponent is, we, guys, deserve this ... „. On the other hand, when speaking about what they have already achieved, he excluded himself and addressed only the players: „You have already done it. In what sense? Individually, fighting for your own reputation. All of you who are here today, everyone already knows about you. Top professional careers are waiting for you ... ». Therefore, the coach did not take the credits for what they have already achieved, but shared the responsibility for what was yet to happen on the field. It can be assumed that modesty in his expression was motivating to the players (they already know that they can achieve a lot), he gave them courage and confidence before the upcoming match (they are not alone, they are together with the coach) and pointed out the significance of the coach's role in the team.

Furthermore, Table 2 shows that his speech is dominated by positive emotions, which are significant for competitive anxiety. In the last discourse unit "Call” there were none of them included. According to the results of this analysis, the personality traits that can be indirectly identified from this speech by Mr. Paunovic are extroversion (correlating with positive emotions and contextually identified social processes), cooperation (more positive and less negative emotions), conscientiousness (correlating with positive emotions and the use of the pronouns in second person).

In summary, the analysis of the three discursive units singled out the twelve, in our opinion, most important messages, i.e. meaningful units that constitute a backbone of the motivational speech by the coach Paunovic addressing his young national team. They are the following:
1. Inviting the players to enjoy the game, without any pressure.

2. Referring to the opponent in general, without exaggeration or depreciation (..."Brazil...Whoever our opponent is...").

3. Calling for the instinct (..."Basic urge, to play, win.. Born to win this trophy...").

4. Raising the players' self-confidence („You have already excelled...").

5. Enhancing the players' self-confidence by addressing the future („Top professional careers are waiting for you...").

6. Defining the first and main goal („Today we need to play for the team...").

7. Defining the reward (Trophy: this should be ours...").

8. Relativization in order to reduce pressure before the match („Anyway, we should only give our best...").

9. Comparison with the graduation, a maturity test („Today is our graduation day! We are taking the final exam, we are graduating today! We are going home with the gold!").

10. Gathering individuals into a team („I want you all to hug each other. As we did last time, please hug each other, everyone... I want you all to look each other in the eyes... To feel the unity...).

11. Respecting individual needs (Anyone who needs to keep their eyes closed, let them do so.").

12. Giving a promise to his team (,...To do it for each other ...").

Generally, the messages are colored with positive emotions. The coach emphasized the beauty of the game and, in any way possible, tried to motivate the players and reduce the pressure before the final match. The players' attention was focused on the team by his call for unity and uniqueness. During his speech he pointed out the goal, but also that he was assured that the goal can be achieved. 


\section{CONCLUSION}

The aim of this analysis was double oriented:

Firstly, the intention was to present the professional characteristics of a coach, i.e. the characteristics of a successful national coach and, by analyzing his motivational speech held before the final game, to determine the words which, to a certain extant, contain messages that may be considered desirable in the Serbian cultural environment. In response, an interested reader may draw a conclusion about the characteristics of the general cultural milieu of the society in which the speech was assessed as successful. By analyzing the discourse of the coach Paunovićs speech, some more facts and conclusions about it can be presented as follows:

- the speech was clear, with precisely defined goals, it was very motivating for the players;

- the coach did not humiliate nor depreciate the opponent's national team;

- there were no threats, pressures or negative

\section{REFERENCES}

1. Ber, V. (2001). Uvod u socijalni konstrukcionizam. [Introduction to social constructionism. IN Serbian]. Beograd: Zepter book world.

2. Bjekić, J. Lazarević, LJ., Erić, M., Stojimirović, E. i T. Đokić: (2012). Razvoj srpske verzije rečnika za automatsku analizu teksta.[ Development of the Serbian version of the dictionary for automatic text analysis. In Serbian]. Psihološka istraživanja, 15 (1), 90-108.

3. Cassidy T., Jones R. \& Potrac P. (2004). Understanding sports coaching. The social, cultural and edagogical foundation of coaching practices. London and New York: Routledge. Retrived 06. 03. 2017., na https://coachiwan.files.wordpress. com/2012/10/coaching.pdf.

4. Courtney, B. C., John, V. P. \& Hymes, D. (1976). Function of Language in the Classroom. London: Teacher College Press.

5. Crisfield, P., Cabral, P. \& Carpenter, F. (2003). The successful coach, guidelines for coaching practice. Leeds, UK: The National Coaching Foundation.

6. Fairclough, N. (2003). Analysing Discourse: Textual Analysis for Social Research. Textual analysis for social researches. London and New York: Routledge. Retrived 07.03.2017. na: http://books. google.com/books?id=5-gXEMPINsEC\&hl=sr. emotions included in the speech;

- the coach shared the merits for the results achieved at the previous stages of the FIFA U-20 World Cup with his players, he also shared the responsibiity for the future challenge with them, he emphasized the beauty of the game and the unity of the team, which makes the essence and definition of sport; he did not refer to the technical part of the game and he did not address the individuals.

Secondly, Mr. Paunovic's motivational speech which was addressed to the Serbia's U-20 national football team players in the final match on FIFA U-20 World Cup (2015) was very important from the pedagogical point of view on the coaching profession. The coach showed his implicit philosophy based on which he has also gained his great authority. The coach Paunović has acted as a positive behaviour model to young people, through educating and motivating the players, but also to the general public, through the media.

7. Galić, M. (2010). Pedagoški rad u savremenom sportu. [Pedagogical work in modern sports. In Serbian]. Beograd: Bojs.

8. Gee, J.P. (1996). Social Linguistic and Literacies, in: Ideology in Discourses. Clark University, USA.

9. Kidman, L. (2001). Developing Decision Makers: An Empowerment Approach to Coaching. Christchurch, NZ: Innovative Press.

10. Krnjaja, Ž. (2009). Kontekst u učenju i podučavanju. [Context in learning and teaching. In Serbian]. Beograd: Zadužbina Andrejević.

11. Leidl, D. \& Frontiera J. (2009). A Qualitative Analysis of Motivational Efforts Employed by Elite Lacrosse Coaches. Journal of Coaching Education 2:1:73-98.

12. Oljača, M. (2001). Pedagogija sporta. [Pedagogy of Sports. In Serbian]. Beograd: Sportska akademija.

13. Robinson, P. (2010). Foundations of Sports Coaching. London and New York: Routledge. Retrived 07. 03. 2017., na https://coachiwan. files.wordpress.com/2012/10/foundations_of_ sports_coaching.pdf.

14. Vargas-Tonsing, T. M., \& Bartholomew, J. B. (2006). An exploratory study of the effects of pregame speeches on team efficacy beliefs. Journal of Applied Social Psychology, 36:4.918-933.. 


\title{
ANÁLISIS DEL DISCURSO DE MOTIVACIÓN DEL SELECCIONADOR EN VÍSPERAS DEL PARTIDO FINAL DE LA COPA MUNDIAL DE FÚTBOL PARA LOS JÓVENES JUGADORES (SUB-20)
}

\begin{abstract}
Resumen
En la literatura contemporánea más a menudo se menciona que un entrenador deportivo debe ser moral, autoritario, educado, comunicativo... No cabe duda que un entrenador debería ser así, pero relativamente poco se sabe de lo que es un entrenador exitoso. Al entrenador le motiva su conocimiento, experiencia, pero también una filosofía implícita, unos factores de motivación más profundos y ocultos, una convicción y postura de sí mismo, de su papel, de un deportista individual o del equipo completo. La práctica demuestra que estos atributos del entrenador influyen al funcionamiento de un equipo deportivo. El objeto del presente trabajo se refiere a los conocimientos que podrían subsumirse bajo la filosofía implícita de un entrenador exitoso. El contexto metodológico es la aplicación de análisis de discurso en el reconocimiento semántico y significativo del discurso de un entrenador exitoso. Buscando la respuesta sobre el objeto y objetivo del trabajo, se ha hecho un análisis del discurso de motivación del seleccionador Paunovic a los jugadores de la selección juvenil de futbol de Serbia en vísperas del partido final con Brasil en el CM para los jóvenes en Nueva Zelanda FIFA (2015). Por los pasos metodológicos el discurso del seleccionador Paunovic está dividido en tres conjuntos discursivos, analizados a través de los mensajes a los jugadores. Los resultados de análisis demuestran que los mensajes del seleccionador se caracterizan por la dignidad, invitación a la unidad y a la responsabilidad. No hay mensajes que se refieren al desprecio o engrandecimiento de la importancia del equipo contrario, han faltado los consejos profesionales, no hay amenazas, ni expresiones de emociones negativas. La conclusión de este análisis son los mensajes explícitos de importancia para la pedagogía, sicología, axiología del deporte, pero también para la tecnología del deporte y del fútbol en particular.
\end{abstract}

Palabras claves: ANÁLISIS DEL DISCURSO/ SELECCIONADOR / DISCURSO DE MOTIVACIÓN/ FIFA COPA MUNDIAL / FUTBOL/ SERBIA

Reacived: 02. 11. 2017. Accepted: 30.03.2018. 


\title{
АНАЛИЗА МОТИВАЦИОНОГ ГОВОРА СЕЛЕКТОРА ПРЕД ФИНАЛНУ УТАКМИЦУ СВЕТСКОГ ПРВЕНСТВА У ФУДБАЛУ ЗА МЛАДЕ ИГРАЧЕ ФИФА (ЦЕ/20)
}

\author{
Бранка Савовић ${ }^{1}$, Милица Убовић ${ }^{2}$, Сандра Раденовић ${ }^{1}$ \\ ${ }^{1}$ Универзитет у Београду, Факултет спорта и физичког васпитања, Србија \\ ${ }^{2}$ Пријатељи деце Београда
}

\begin{abstract}
Сажетак
У савременој литератури најчешће се наводи да спортски тренер треба да буде моралан, ауторитативан, образован, комуникативан.... Неспорно је да би тренер такав и требало да буде али се релативно мало зна о оном што успешан тренер јесте. Тренера покреће његово знање, искуство али и имплицита филозофија, дубљи и скривени мотивациони фактори, уверења и ставови о себи, својој улози, поједином спортисти или целини тима. Пракса показује да ови атрибути тренера утичу на функционисање спортског тима. Циљ рада је педагошки осврт на васпитно деловање спортског тренера. Предмет рада се односи на сазнања која би могла да се подведу под имплицитну филозофију успешног тренера. Меотодолшки контекст је примена анализе дискурса у семантичком и смисленом препознавању говора успешног тренера. У доласку до одговора на предмет и циљ рада, извршена је анализа мотивационог говора селектора Пауновића играчима омладинске фудбалске репрезентације Србије пред финалну утакмицу са Бразилом на СП за младе на Новом Зеланду ФИФА (2015). Методолошким корацима, говор селектора Пауновића је подељен је на три дискурзивне целине, анализиране кроз поруке играчима. Резултати анализе указују да поруке селектора одликује достојанство, позив на јединство и одговорност. Нема порука које се односе на омаловажавање или преувеличавање значаја супарничког тима, изостали су професионални савети, нема претњи и изражавања негативних емоција. Закључак ове анализе су експлицитне поруке од значаја за педагогију, психологију, аксиологију спорта, али и технологију спорта и фудбала појединачно.
\end{abstract}

КљУчне речи: АНАЛИЗА ДИСКУРСА / СЕЛЕКТОР / МОТИВАЦИОНИ ГОВОР / СВЕТСКО ПРВЕНСТВО / ФУДБАЛ / СРБИЈА /

\section{УВОД}

У савременој литератури се може наћи релативно велики број радова посвећених истраживањима личности и особености квалитетног спортског тренера. Најчешће се наводи да тренер треба да буде моралан, ауторитативан, добро образован за свој посао, тимски играч, комуникативно компетентан и др. (Галић, 2010; Ољача, 2001). Робинсон (2010) наводи да је важно да тренер буде добар планер, аналитичар, неко ко је способан да креира и одржи „сигурно окружење” погодно за тренирање, раст и развој сваког појединца. Тренер поседује способност да ефикасно комуницира са другима, даје конструктивне повратне информације, као и да буде мотивисан за континуирано учење и напредовање (Crisfield et al., 2003). У опису ангажовања често се наводи безусловна љубав и прихватање као нешто што тренери треба да негују у раду са појединцима, групама и целином тима. Показивање бриге за сваког спортисту, играча, интересовања за оно што им се дешава у животу, чини да се у тиму развија осећај јединства и прихваћености од стране сваког члана. Тренери треба перманентно да уче и да се усавршавају, врло је важна њихова отвореност за учење (Cassidy et al, 2004). Посао тренера је технолошки и васпитно сложен процес који је испуњен интерактивним учењем. Учење је, надаље, процес грађења смисла, стални социјални процес током којег се значења размењују кроз 
сопствену активност и деловање (Krnjaja, 2009). Тренер је особа која стално учи кроз интеракцију са другима (играчима, сарадницима, публиком, навијачима и сл.) и тиме мења себе и своју визију професије, самим тим доприноси и заједници у којој живи. У овом раду тренер се сагледава као лидер и тимски играч, сарадник у процесу учења који уважава особености и искуства сваког поједнца и тежи реализацији заједничких циљева. Партнерским односима са многобројним актерима, заснованом на поштовању и дистрибуцији значаја, дијалогу и изградњи заједничког значења, тренер ствара заједнички контекст тима и креира окружење у коме сваки од актера учи, развија се и напредује. Поред образовања, васпитања и искуством стечених квалитета, сваки тренер има и своју имплицитну професионалну филозофију. Имплицитна професионална филозофија указује на дубље и скривене мотивационе факторе који га опредељују као тренера. Ово је анализама теже доступно подручје у изградњи професионалне компетентности и исто је испуњено уверењима и ставовима о себи, својој улози, тиму, ситуацији у којој се тим тренутно налази и будућим задацима. Пракса показује да управо ова уверења тренера на најдиректнији могући начин утичу на функционисање тима. Имплицитна професионална филозофија тренера би се могла сагледати као сет моралних уверења и ставова који обликују његово понашање у различим професионалним и животним ситуацијама, при чему, различити тренери имају различите имплицитне филозофије о томе која је њихова улога у тиму, због чега се баве тренерским послом (Робинсон, 2010). Имплицитне филозофије тренера могу да утичу на начин њихове перцепције појединих играча и сарадника, а самим тим и на природу успостављања односа. Зато је важно да се током процеса изградње професионалне компентентости тренера ради на свесности о властитој имплицитној филозофији, да процес професионалног развоја прати анализа и промена властитих уверења и ставова. Битно је да се тај процес промишљања одвија континуирано, пре, током и након одређене тренажне и такмичарске активности. Важно је да код самог тренера постоји свест о томе да његова властита уверења и искуства утичу и на педагошке одлуке које доноси у свом раду.

С обзиром да је предмет овог рада анализа мотивационог говора тренера пред одлучујућу утакмицу, важно је истаћи значај говора за сам ток меча. Мотивациони говори су ти који инспиришу и повећавају ефикасно делање самог тима, при чему се разликују три врсте говора (Vargas-Tonsing \& Bartholomew, 2006): (I) говор „контроле", (II) стратегијско-орјиентисани говор и (III) емоционални говор за кога аутори кажу да највише мотивише играче, будећи да се у њиму налазе снажне емоције о потенцијалном успеху тима. Садржај говора је од посебне важности јер кроз њега тренер може да исказује интимне и дубоке емоције поводом предстојеће утакмице, као и велику жељу да његов тим наступи са сампоуздањем и поносом (Leidl, D. \& Frontiera, 2009).

Недовољан је број научних евиденција које се односе на истраживања оног што успешан тренер јесте. Особеност сваког човека утемељена је оригиналним генетским склопом. Особеност тренера зависи и од његовог животног и спортског искуства, али и квалитета образовања што чини његову личну и имплицитну филозофију. Стога, циљ овог рада је прикупљање нешто више чињеница у правцу откривања деловања успешног тренера у моменту одлучујућег спортског догађаја. Анализом дискурса као методом овог рада, настоје се открити ставови, мишљења, емоције.... које чине његову професионалну динамику и које га, уједно, чине особеним.

Дискурс се препознаје и као извор сазнања и процес током којег се вербална и невербална комуникација анализира у односу на одређени контекст. Говор и контекст чине комуникациону ситуацију. Другим речима, сам текст (говор) и контекст представљају комуникациону целину, погодну за анализирање дискурса. Анализирањем говора, разговора (семантички и лингвистички контекст), истраживач рашчлањује, трага за значењима и вредностима који из садржаја анализе произлазе (методолошки контекст). Речју, трага се за препознавањем и верификацијом имплицитне филозофије особа које учествују у комуникативној ситуацији.

Предмет овог рада је је анализа комуникационе ситуације у којој се тренер обраћа играчима пред одлучујућу утакмицу - финале светског првенства. Конкретно, анализиран је говор господина Вељка Пауновића, селектора омладинске фудбалске репрезентације Републике Србије, пред финалну утакмицу Светског првенства у фудбалу против репрезентације Бразила. Утак- 
мица се играла 2015. године на ФИФА Светском првенству за фудбалере до 20 година на Новом Зеланду, у Окленду. У тој утакмици, млади репрезентативци Србије су победили репрезентацију Бразила резултатом 2:1. Разлог за ову анализу је афирмација научне и професионалне радозналости аутора подстакнута практичним питањима и тврђењима која су постављена у јавности Србије и то:

- за успех омладинске репрезентације најзаслужнији је селектор. Јак утисак на стручну и ширу јавност оставио је његов мотивациони говор пред почетак финалне утакмице;

- играчи су као фактор од значаја за исход утакмице истакли вођење и мотивациони говор селектора пред финалну утакмицу.

У тренажној пракси је познато да се утакмица добија (или губи) и на менталном плану. Често се дешава да јачи противник изгуби утакмицу од потенцијално слабијег (и обрнуто) због имплицитних уверења играча. При том мотивациони говор тренера пред утакмицу, по мишљењу струке као и самих играча, има значајног утицаја на играче и током самог такмичења. Мотивациони говори тренера пред финалну утакмицу су врло разнолики. Захваљујући савременој технологији али и нарастањем потреба да се осветли пракса и модели понашања успешних, данас се они бележе и анализирају. Тако и самим претраживањем интернета се стиже до блогова са „најбољим мотивационим говорима тренера“. Већ током преслушавања, уочава се да се говори разликују по много фактора. Различитост потиче од особености тренера, његових играча, али и у односу на такмичрску ситуацију и културне вредности које се негују у датом друштву. Тако, поједини снимци мотивационих говора обилују борбеним покличима, борбеном музиком у позадини говора. Има и оних говора који су супротно свим вредностима спорта испуњени настојењем да се понизи противник. Изгледа као да се различити мотивациони говори уклапају у културне вредности, будући да су играчи позитивно реаговали на говор. Стога, једно од истраживачких питања могло би да буде да ли се путем анализе комуникационог контекста у спорту може извести неки закључак о друштву из кога спортисти долазе. Наравно, трагање за одговором на ово питање је могуће само када су сви спортисти део исте културне заједнице. За разлику од хетереогености састава тимова у професионалним екипама, у репрезентативним селекцијама постоји изразита хомогеност. Дакле, једно од истраживачких питања, о коме би се могло спекулисати, било би: који елементи говора чине добар мотивациони подстицај за фудбалере из Србије? Најзад, истраживачки проблем је педагошки оријентисан. Занима нас има ли, и у којој мери, васпитних садржаја у мотивационом говору намењеном младим играч.

\section{МЕТОД РАДА}

Метод у овом раду је анализа дискурса. Анализа дискурса је истраживачки приступ погодан за трагање за значењем одређеног текста у оквиру датог контекста (Ber, 2001). Као педагошка анализа у широј употреби је од 1988. након објављивања публикације о дискурсу разреда Кортнија (Courtney), професора заслужног за покретање истоименог курса на Харвард универзитету. Од тада, доживела је многобројне методолошке, семантичке, лингвистичке, гносеолошке, епистемиолошке варијације (Gee, 1996, Faircough 2003, Ber, 2001). Данас се сматра једном од најприхваћенијих социолошких и педагошких квалитативних анализа која води до објективних квалитативних закључака.

Методолошки кораци у реализацији анализе дискурса допуњени су анализама текста применом два софтверска програма. Први је Voyant програм за анализу текста. Програм је погодан за указивање на фреквентност речи и везе унутар текста и за препознавање „чворних“ места у тексту. Други је LIWC (Linguistic Inquiry and Word Count) програм, тренутно најбоље процењен програм за анализу текста (Бјекић и сар. 2012). Аутори овог текста су свесни тренутних лингвистичких, самим тиме и методолошких ограничења српске варијанте овог софтвера. Из тог разлога, коришћена је енглеска варијанта програма. За анализу, говор господина Пауновића је преведен на енглески језик, анализиран путем LIWC софтвера, а затим су резултати за потребе овог рада преведени на српски и табеларно приказани.

Употреба LIWC програма омогућује квантитативну анализу употребљених речи. Сваку појединачну реч програм препознаје као јединицу која улази у састав одређене категорије. Категорије су неопходне да би се смисао речи одредио у складу 
са контекстом. Сам програм садржи око 4500 унапред дефинисаних категорија преко којих се унесени текст упоређује и анализира. Будући да програм препознаје графемске случајеве сваке речи и да их региструје контекстуално, као лингвистичке категорије, исти предодређује лингвистички стил говорника. Преко лингвистичког стила, програм, препознаје атрибуте говора и указује на базичне димензије у опхођењу анализиране особе. На пример, димензија „Сарадљивост“ која се издваја у сафтверској схеми, у негативној је корелацији са речима које контекстуално одражавају негативне емоције. Екстраверзија корелира са речима које одражавају позитивне емоције и која контекстуално указују на социјалне процесе. Она је повезана и са укупном продукцијом речи особе која мање формалним језиком, употребом заменица у другом и трећем лицу множине, маркира социјалну свесност и ангажованост (Pennebaker et al., 2003. према Бјекић, J. и сар. 2012). Димензиjа "Савесност" позитивно корелира са употребом заменица у другом лицу множине и са позитивним емоцијама, итд. Програм унесене податке анализира у односу на просечне уобичајене личне текстове, поруке (говоре у неформалним ситуацијама) и у односу на формалне текстове (говори за јавност, пословне преписке, предавања и сл).

\section{РЕЗУЛТАТИ И ДИСКУСИЈА}

Мотивациони говор селектора Пауновића и контекст у којем је обављен постао је јаван (и тиме доступан анализи) посредством савремених медија (http://mondo.rs/a806821/Sport/Fudbal/ Veljko-Paunovic-sampionski-govor-pred-finale-SrbijaBrazil.html). Преносимо га у целини:

"Сви ми имамо испит зрелости. Уосталом, данас је на најбољи и најлепши могући начин наша зрелост испраћена. Данас имамо матуру, фудбалску. Играмо финале Светског првенства са најбољим могућим ривалом на свету. Са Бразилом. И хоћу да вам кажем - да данас треба да уживамо. Никакав притисак не треба да имамо, сем тога што желимо да победимо. То је онај основни притисак због кога смо рођени, због кога играмо фудбал. Да уживамо и победимо, је л' тако? Хоћу да вам кажем, да данас нико не треба посебно да се истиче. Ви сте се већ истакли. У ком смислу? Појединачно, да се бори за своју неку репутацију.
Сви ви који сте овде, сви за вас већ знају. Све вас чека врхунска каријера. Данас треба да играмо за тим. Данас треба да будемо јединствени, као што смо били до сада. И још више! Како год да се зове наш противникмомци, заслужили ово. Овај трофеј (показује прстом на фотографију). Ми смо, момци, рођени да освојимо овај трофеј. Гледајте га добро, ово треба да буде наше. Како год буде било, само да дамо све од сеঠе. Као што смо давали до сада. Данас мора печат да буде (ударац песницом о длан). Данас је матура! (нови „печат” песницом). Данас полажемо испит, данас узимамо диплому! Идемо кући са златом! Сад хоћу сви да устанемо, момци. Хоћу да се загрлимо сви, као што смо урадили прошли пут сви, да се сви загрлимо. И хоћу следеће, момци, нећемо сада да читамо молитву, сада хоћу да се гледамо у очи. Коме треба да жмури, нека зажмури. И нека мисли због чега смо заслужили ово. Шта је свако од вас урадио у животу због чега је урадио ово (показује на фотографију трофеја). Шта је свако од нас и за кога хоће да освоји ово. Загрлите се, да осетимо један другога. Минут ћемо један да одћутимо. Да осетимо јединство. Да свако свакога погледа у очи и да каже један другоме да ће то урадити један за другога. Да ће то урадити за нас, за све нас"

Говор господина Пауновића траје 2 минута 66 секунди. Укупан број употребљених речи је 325. Контекст у којем је изговорен је следећи: Нови Зеланд, последње окупљање тима пре почетак финалне утакмице, сала за састанке екипа. Селектор стоји лицем окренут играчима, иза њега је екран.

Контекст текста је анализиран кроз више нивоа. У првом је исти подељен на три смисаоне целине, и то: (1) Освешћивање (2) Задатак и (3) Позив на јединственост и јединство.

У методолошком смислу, смисаоној целини „Освешћивање ситуације“ (у даљем тексту: Ситуација) припадају следећи делови текста: „Сви ми имамо испит зрелости. Уосталом, данас је на најбољи и најлепши могући начин наша зрелост испраћена. Данас имамо матуру, фудбалску. Играмо финале Светског првенства са најбољим могућим ривалом на свету. Са Бразилом. И хоћу да вам кажем - да данас треба да уживамо. Никакав притисак не треба да имамо, сем тога што желимо да победимо. То је онај основни притисак због кога смо рођени, због кога играмо фудбал. Да уживамо и победимо, је л' тако?" 
Смисаоној целини: „Задатак“ припадају следећи делови текста: „Хоћу да вам кажем, да данас нико не треба посебно да се истиче. Ви сте се већ истакли. У ком смислу? Појединачно, да се бори за своју неку репутацију. Сви ви који сте овде, сви за вас већ знају. Све вас чека врхунска каријера. Данас треба да играмо за тим. Данас треба да будемо јединствени, као што смо били до сада. И још више! Како год да се зове наш противник, ми смо, момци, заслужили ово. Овај трофеј (показује прстом на фотографију). Ми смо, момци, рођени да освојимо овај трофеј. Гледајте га добро, ово треба да буде наше. Како год буде било, само да дамо све од сеঠе. Као што смо давали до сада. Данас мора печат да буде (ударац песницом о длан). Данас је матура! (нови „печат” песницом). Данас полажемо испит, данас узимамо диплому! Идемо кући са златом!”

Смисаоној целини „Позив на јединственост и јединство“ (у даљем тексту: Позив) припадају следећи делови текста:

„Сад хоћу сви да устанемо, момци. Хоћу да се загрлимо сви, као што смо урадили прошли пут сви, да се сви загрлимо. И хоћу следеће, момци, нећемо сада да читамо молитву, сада хоћу да се гледамо у очи. Коме треба да жмури, нека зажмури. И нека мисли због чега смо заслужили ово. Шта је свако од вас урадио у животу због чега је урадио ово (показује на фотографију трофеja). Шта је свако од нас и за кога хоће да освоји ово. Загрлите се, да осетимо један другога. Минут ћемо један да одћутимо. Да осетимо јединство. Да свако свакога погледа у очи и да каже један другоме да ће то урадити један за другога. Да ће то урадити за нас, за све нас"

У следећем кораку анализирани су текст у целини као и свака од целина понаособ..

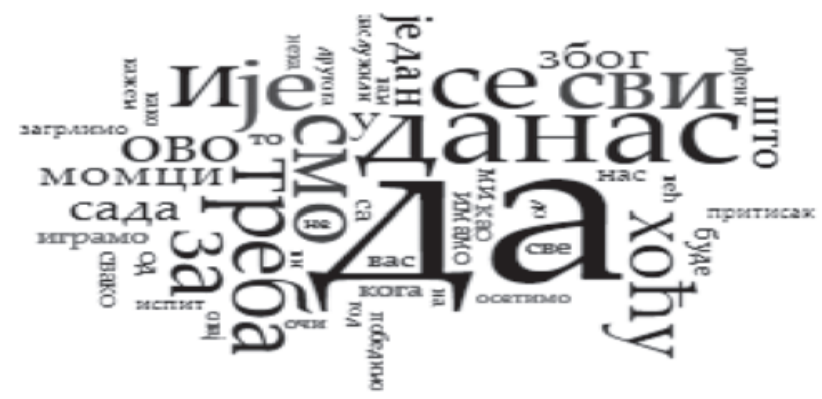

Слика1. Речи са највећом фреквенцијом у говору селектора Пауновића (резултат Voyant програма за анализу текста)
На основу величине фонта визуелно је процењена фреквентност одређених речи. Увидом у Слику 1 уочава се да у тексту доминирају речи : да, данас, уживамо, победимо, играмо ипритисак. Ове речи чине окосницу целокупне поруке. Генерално, осим речи “притисак”, све остале одражавају позитивне поруке и емоције упућене играчима. Везе између најфреквентнијих речи целокупног текста приказане су на слици 2:

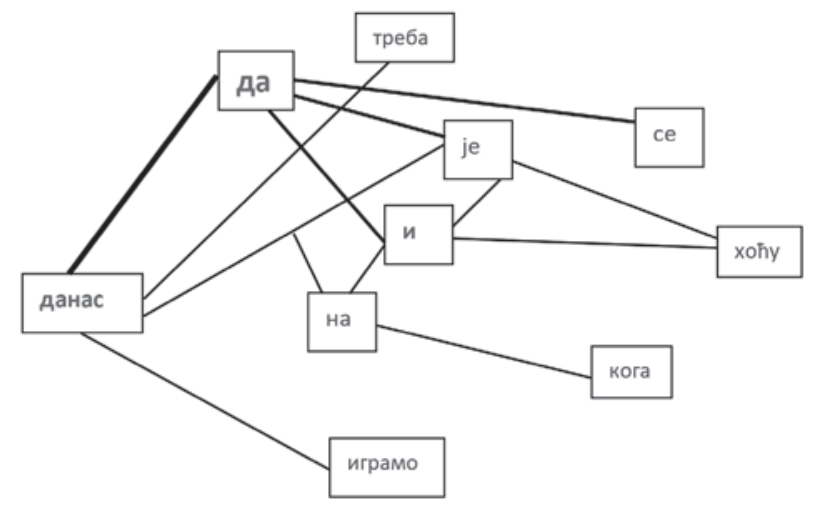

Слика 2. Везе унутар анализираног говора селектора Пауновића

Доминирају речи да, треба, хоћу, данас, играмо. Везник да је централно место у граматичком смислу и семантички нема значаја, будући да повезује изразе треба, хоћу, данас и играмо. Анализом веза унутар целог текста види се да тренер наглашава вредност игре као такве, а не победе, такмичења. Не инсистира на притиску. Не доминира освртање на противника. Нема претњи, нема наглашавања озбиљности ситуације. Анализа овог гогора постаје још јасније када се сагледају вербални чворови унутар текста (Слика 3).



Слика 3. Везе унутар вербалног чвора целине „Задатак“ 
Као што је приказано на слици 3, основна порука селектора младој репрезентацији је „хоћу, треба, желимо (да) данас уживамо, победимо. Ове, позитивно оријентисане дискурзив- не поруке доминирају и целокупним текстом. И LIWC анализом утврђено је да текст одудара од уобичајених формалних и личних порука (Табела 1).

Табела 1. Анализа текста говора селектора Пауновића (LIWC софтвер)

\begin{tabular}{|c|c|c|c|}
\hline LIWC анализа & Говор селектора & $\begin{array}{c}\text { Личне поруке } \\
\text { (средње вредности) }\end{array}$ & $\begin{array}{c}\text { Формаизован говор } \\
\text { (средње вредности) }\end{array}$ \\
\hline $\begin{array}{c}\text { Лично реферисање (jа, моје, } \\
\text { мене..) }\end{array}$ & 9,27 & 11,4 & 4,2 \\
\hline $\begin{array}{c}\text { Социјалне речи (ми, сви, } \\
\text { наше..) }\end{array}$ & 16,29 & 9,5 & 8,0 \\
\hline Позитивне емоције & 3,65 & 2,7 & 2,6 \\
\hline Негативне емоције & 0,84 & 2,6 & 1,6 \\
\hline
\end{tabular}

Резултати LIWC анализе преведени су на српски језик а све табеле су прилагођене конкретним задацима ове анализе. Из резултата произилази да је господин Пауновић употребио значајно већи број социјалних речи (ми, желимо, сви, итд) , значајно већи број речи које контекстуално указују на позитивне емоције изначајно мањи број речи са негативним емоцијама у односу на средње вредности истих у личном и формалном говору.

Полазећи од модела анализе за ситуацију Задатак, сачињене су и анализе за преостале две ситуације. 3бирно, све три издвојене и анализиране ситуације су приказане на слици 4.
1. Ситуација



2. Задатак

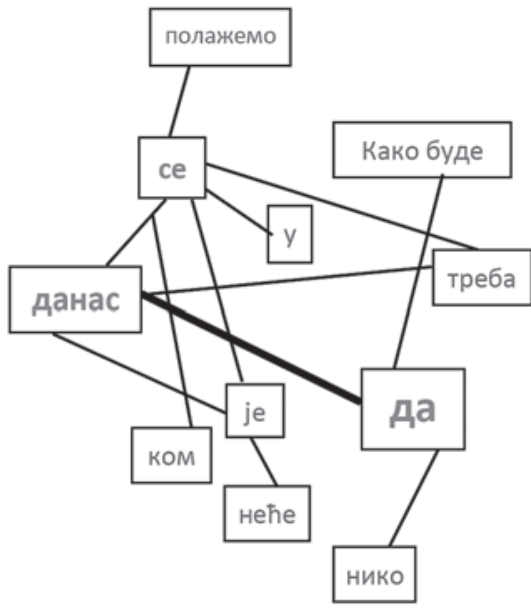

3. Позив

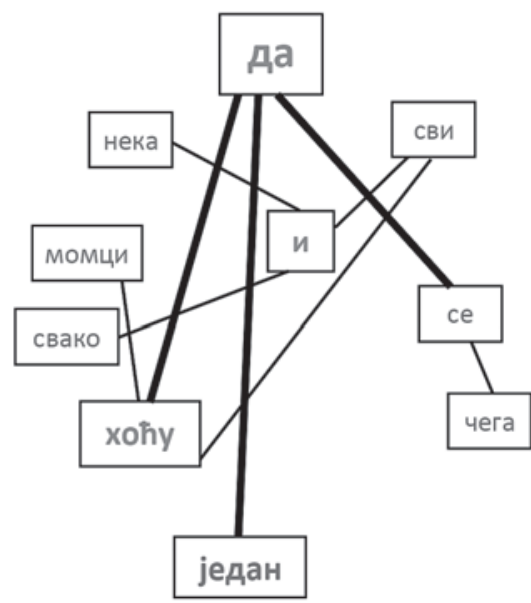

Слика 4. Приказ веза у дискурзивним целинама

У првој дискурзивној целини, текстуалне везе успостављене су између речи и сложеница „Данас, имамо, уживамо, никакав (притисак)“. У другој, доминирају „Данас, треба, да полажемо, па како буде“, а у трећој то су „Момци, данас, хоћу, један (другога, другоме), сви, свако“.

Упоредна анализа дискурса све три ситуцаије дата је у Табели 2. 
Табела 2. LIWC анализа дискурзивних целина текста преведена на српски језик

\begin{tabular}{|c|c|c|c|c|c|}
\hline LIWC анализа & 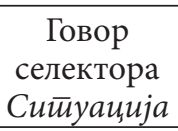 &  & $\begin{array}{c}\text { Говор } \\
\text { селектора } \\
\text { Позив } \\
\end{array}$ & $\begin{array}{c}\text { Личне поруке } \\
\text { (средње } \\
\text { вредности) }\end{array}$ & $\begin{array}{c}\text { Формаизован } \\
\text { говор (средње } \\
\text { вредности) }\end{array}$ \\
\hline Лично реферисање (ја, моје, мене..) & 10,71 & 10,16 & 9,77 & 11,4 & 4,2 \\
\hline Социјалне речи (ми, сви, наше..) & 10,71 & 20,31 & 13,53 & 9,5 & 8,0 \\
\hline Позитивне емоције & 10,71 & 3,12 & 0,75 & 2,7 & 2,6 \\
\hline Негативне емоције & 2,38 & 1,56 & 0.00 & 2,6 & 1,6 \\
\hline
\end{tabular}

Господин Пауновић је употребио већи број социјалних одредница („ми, нас“) него што је то уобичајено у личним и формалним говорима. Њихов највећи број се региструје у другој дискурзивној целини условно названој „Задатак“. Из текста се види да тренер ове одреднице користи када говори о будућем, напорном подухвату: “Данас треба да играмо за тим. Данас треба да будемо јединствени, као што смо били до сада. И још више! Како год да се зове наш противник, ми смо, момци, заслужили ово...... Са друге стране, када говори о већ постигнутим заслугама, он себе изузима и обраћа се искључиво играчима: "Ви сте се већ истакли. У ком смислу? Појединачно, да се бори за своју неку репутацију. Сви ви који сте овде, сви за вас већ знају. Све вас чека врхунска каријера...”. Дакле, селектор у овом случају не преузима на себе заслуге за већ постигнуто, већ са играчима дели одговорност за оно што тек треба да се деси на терену. Може се претпоставити да скромност у исказу делује мотивишуће на играче (већ знају да могу много), даје им храбрости и самопоуздања пред предстојећи меч (нису сами, са тренером су) и указује на величину улоге селектора у тиму.

Надаље, из Табеле 2 се види да говором доминирају позитивне емоције, које су значајне за такмичарске анксиозности. У последњој дискурзивној целини “Позив" их уопште нема. Према резултатима ове анализе, индикректно, димензије личности које се могу препознати из овог говора господина Пауновића су екстраверзија (корелира са позитивним емоцијама и контекстуално препознатим социјалним процесима), сарадљивост (више позитивних, а мање негативних емоција), савесност (корелира са позитивним емоцијама и употребом заменица у другом лицу).

3ठирно, анализа три дискурзивне целине издвојила је дванаест, по нашем мишљењу најбитнијих порука, смисаоних целина које чине окосницу мотивационог говора селектора Пауновића младој репрезентацији. То су:
1. позив играчима да уживају у игри, без притисака

2. осврт на противника је на општем нивоу, без преувеличавања или омаловажавања („Бразил...Како год да се зове“)

3. позив на инстикт („..Основни, да играмо, победимо... Рођени да освојимо овај трофеј..“)

4. подизање самопоуздања играча („Ви сте се већ истакли...").

5. учвршћивање самопоуздања играча освртом на будућност („Све вас чека врхунска каријера")

6. дефинисање првог и основног циља („Данас треба да играмо за тим“).

7. дефинисање награде (Трофеј: „Ово треба да буде наше").

8. релативизовање зарад смањења притиска пред утакмицу („Како год буде било, само да дамо све од себе")

9. поређење са матуром, испитом зрелости (“Данас је матура! Данас полажемо испит, данас узимамо диплому! Идемо кући са златом!")

10. окупљање појединаца у тим („Хоћу да се загрлимо сви...Као што смо урадили прошли пут сви, да се сви загрлимо....Сада хоћу да се гледамо у очи...Да осетимо јединство”..)

11. поштовање индивидуалности („Коме треба да жмури, нека зажмури.")

12. обећање тиму („...Да ће то урадити један за другога").

Генерално, поруке су обојене позитивним емоцијама. Тренер наглашава лепоту игре и на сваки могући начин покушава да мотивише играче и умањи притисак пред финалну утакмицу. Пажњу играча фокусира на тим позивом на јединство. Током говора истиче циљ али и убеђеност у то да је циљ достижан. 


\section{ЗАКЉУЧАК}

Циљ ове анализе дискурса је био двоструко оријентисан:

Прво, намера је била да се прикажу професионалне карактеристике тренера, у овом случају карактеристике успешног селектора и да се анализом мотивационог говора пред финалну утакмицу детерминишу оне речи које, у неку руку, садрже поруке које се могу сматрати пожељним у културној средини Србије. Повратно, заинтересовани читалац може извући закључак о карактеристикама општег културног миљеа друштва у којем је говор процењен као успешан.

Анализом дискурса говора селектора Пауновића може се изнети и нешто више чињеница и закључака о учињеном, и то:

- говор је био јасан, са прецизно дефинисаним циљевима, деловао је врло мотивишуће на играче;

- селектор није омаловажавао ни преувеличавао противничку репрезентацију;

\section{ЛИТЕРАТУРА}

1. Бер, В. (2001). Увод у социјални констирукционизам. Београд: Зептер боок шорлд.

2. Бјекић, Ј. и сар. (2012). Развој српске верзије речника за аутоматску анализу текста. Психолошка истираживана, 15 (1), 90-108.

3. Cassidy T., Jones R. \& Potrac P. (2004). Understanding sports coaching. The social, cultural and edagogical foundation of coaching practices. London and New York: Routledge. Dostupno 06. 03. 2017., na https://coachiwan.files.wordpress. com/2012/10/coaching.pdf.

4. Courtney, B. C., John, V. P. \& Hymes, D. (1976). Function of Language in the Classroom. London: Teacher College Press.

5. Crisfield, P., Cabral, P. \& Carpenter, F. (2003). The successful coach, guidelines for coaching practice. Leeds, UK: The National Coaching Foundation.

6. Fairclough, N. (2003). Analysing Discourse: Textual Analysis for Social Research. Textual analysis for social researches. London and New York: Routledge. Dostupno 07.03.2017. na: http://books. google.com/books?id=5-gXEMPlNsEC\&hl=sr.

7. Галић, М. (2010). Пеgаїошки раg у савременом

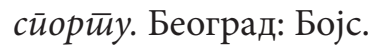

- у говору није било претњи, притисака и негативних емоција;

- селектор је играчима приписао заслуге за постигнуто у претходним нивоима FIFA Са-20a, са њима је преузео одговорност за будући изазов, истакао је лепоту игре и јединственосттима, што чини саму суштину, дефиницију спорта; није се освртао на технички део игре, нити се обраћао појединцима.

Друго, мотивациони говор господина Пауновића упућен игачима тима младе репрезентације Србије на финалној утакмици ФИФА СП У-20 (2015) био је са педагошке тачке гледишта на професију спортског тренера веома значајан. Селектор је показао своју имплицитну филозофију на којој је постигао и величину свог ауторитета. Селектор Пауновић је деловао као позитиван модел понашања младима, васпитно и мотивационо је утицао на играче, али посредством медија и на ширу јавност.

8. Gee, J.P. (1996). Social Linguistic and Literacies, in: Ideology in Discourses. Clark University, USA.

9. Kidman, L. (2001). Developing Decision Makers: An Empowerment Approach to Coaching. Christchurch, NZ: Innovative Press.


чавағу. Београд: Задужбина Андрејевић.

11. Leidl, D. \& Frontiera J. (2009). A Qualitative Analysis of Motivational Efforts Employed by Elite Lacrosse Coaches. Journal of Coaching Education 2:1:73-98.

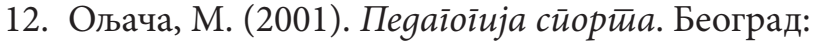
Спортска академија.

13. Robinson, P. (2010). Foundations of Sports Coaching. London and New York: Routledge. Dostupno 07. 03. 2017., na https://coachiwan. files.wordpress.com/2012/10/foundations_of_ sports_coaching.pdf.

14. Vargas-Tonsing, T. M., \& Bartholomew, J. B. (2006). An exploratory study of the effects of pregame speeches on team efficacy beliefs. Journal of Applied Social Psychology, 36:4.918-933. 


\title{
ANÁLISIS DEL DISCURSO DE MOTIVACIÓN DEL SELECCIONADOR EN VÍSPERAS DEL PARTIDO FINAL DE LA COPA MUNDIAL DE FÚTBOL PARA LOS JÓVENES JUGADORES (SUB-20)
}

\begin{abstract}
Resumen
En la literatura contemporánea más a menudo se menciona que un entrenador deportivo debe ser moral, autoritario, educado, comunicativo... No cabe duda que un entrenador debería ser así, pero relativamente poco se sabe de lo que es un entrenador exitoso. Al entrenador le motiva su conocimiento, experiencia, pero también una filosofía implícita, unos factores de motivación más profundos y ocultos, una convicción y postura de sí mismo, de su papel, de un deportista individual o del equipo completo. La práctica demuestra que estos atributos del entrenador influyen al funcionamiento de un equipo deportivo. El objeto del presente trabajo se refiere a los conocimientos que podrían subsumirse bajo la filosofía implícita de un entrenador exitoso. El contexto metodológico es la aplicación de análisis de discurso en el reconocimiento semántico y significativo del discurso de un entrenador exitoso. Buscando la respuesta sobre el objeto y objetivo del trabajo, se ha hecho un análisis del discurso de motivación del seleccionador Paunovic a los jugadores de la selección juvenil de futbol de Serbia en vísperas del partido final con Brasil en el CM para los jóvenes en Nueva Zelanda FIFA (2015). Por los pasos metodológicos el discurso del seleccionador Paunovic está dividido en tres conjuntos discursivos, analizados a través de los mensajes a los jugadores. Los resultados de análisis demuestran que los mensajes del seleccionador se caracterizan por la dignidad, invitación a la unidad y a la responsabilidad. No hay mensajes que se refieren al desprecio o engrandecimiento de la importancia del equipo contrario, han faltado los consejos profesionales, no hay amenazas, ni expresiones de emociones negativas. La conclusión de este análisis son los mensajes explícitos de importancia para la pedagogía, sicología, axiología del deporte, pero también para la tecnología del deporte y del fútbol en particular.
\end{abstract}

Palabras claves: ANÁLISIS DEL DISCURSO/ SELECCIONADOR / DISCURSO DE MOTIVACIÓN/ FIFA COPA MUNDIAL / FUTBOL/ SERBIA

Примљен: 02. 11.2017

Прихваћен: 30. 03. 2018. 